\title{
Progress in studies of epidermal stem cells and their application in skin tissue engineering
}

\author{
Ronghua Yang ${ }^{1 \dagger}$, Shuai Yang ${ }^{2+}$, Jingling Zhao ${ }^{3}$, Ximin $\mathrm{Hu}^{4}$, Xiaodong Chen ${ }^{1}$, Jingru Wang ${ }^{1}$, Julin $\mathrm{Xie}^{3^{*}}$ and \\ Kun Xiong ${ }^{5,6^{*}}$
}

\begin{abstract}
The epidermis, which is the outermost layer of mammalian skin, provides an essential barrier that is essential for maintenance of life. The epidermis is a stratified epithelium, which is maintained by the proliferation of epidermal stem cells (EPSCs) at the basal layer of the epidermis. As a unique cell population characterized by self-renewal and differentiation capabilities, EPSCs ensure the maintenance of adult skin homeostasis and participate in repair of the epidermis after injury. Recently, the utilization of EPSCs for wound healing and tissue regeneration has been attracting increased attention from researchers. In addition, the advances in tissue engineering have increased the interest in applying EPSCs in tissue-engineered scaffolds to further reconstitute injured tissues. In this review, we introduce research developments related to EPSCS, including methods recently used in the culture and enrichment of EPSCs, as well as advanced tools to study EPSCS. The function and mechanism of the EPSC-dermal units in the development and homeostasis of the skin are also summarized. Finally, the potential applications of EPSCs in skin tissue engineering are discussed.
\end{abstract}

Keywords: Epidermal stem cells, EPSC-dermal interaction, Skin tissue engineering, Skin regeneration

\section{Introduction}

Skin provides an interface between organisms and the outer environment, covering the entire surface area of the body. The epidermis is featured by a stratified structure and functions as a protective layer, including body temperature control, sensory perception, preservation of the hydration process, and protection against environmental assaults. Although the epidermis is capable of self-repairing and self-renewing, severe skin damages such as burn can impair the capacity for regeneration

\footnotetext{
*Correspondence: sysxiej190@sohu.com; xiongkun2001@163.com ${ }^{\dagger}$ Ronghua Yang and Shuai Yang contributed equally to this work. ${ }^{3}$ Department of Burn Surgery, First Affiliated Hospital of Sun Yat-Sen University, Guangzhou 510080, Guangdong, China

${ }^{5}$ Department of Anatomy and Neurobiology, School of Basic Medical Science, Central South University, Morphological Sciences Building, 172 Tongzi Po Road, Changsha 410013, Hunan, China

Full list of author information is available at the end of the article
}

and may be life-threatening in severe conditions. As the skin is an immunocompetent organ, autologous skin grafts are the only feasible method to cover serious skin wounds permanently. Despite the development of tissuesaving autologous techniques of transplantation including Meek and mesh grafts, therapeutic strategies for extensive skin injury are seriously limited by the amount of skin available for grafting. Recently, the utilization of EPSCs in the skin regeneration has attracted the attention of researchers. EPSCs residing in the skin and its appendages, such as sweat glands and hair bulbs [1-3], are proliferation units that exhibit slow and limited division, can self-renew, and are responsible for generating the various lineages existing in the mature skin [4-6]. Currently, it is much easier to isolate and obtain wellcharacterized and specific EPSCs by using fluorescenceactivated cell sorting (FACS) and a panel of biomarkers 
[7]. Moreover, the improvements of culture system for EPSCs, such as the combination of serum- and feederfree media with small molecules, as well as the threedimensional (3D) culture system, are important for EPSC expansion and maintenance of EPSC homeostasis in vitro. The use of combination of EPSCs with biomaterial scaffolds provides promising regenerative strategies for engineering skin, stem cell delivery, and regeneration of damaged skin tissues $[8,9]$. In this review, we focus on the progress of techniques in EPSC research, introduce their interactions with different dermal cells, summarize their unappreciated important role as a niche, and highlight the function and mechanism of the EPSC-dermal units in the development and homeostasis of the skin. Finally, we introduce the development of biomaterial scaffolds and discuss the potential clinical applications of EPSC-based tissue-engineered skin in skin repair and regeneration.

\section{Culture and enrichment of EPSCs Methods for enrichment of EPSCs}

The isolation and enrichment of EPSCs is challenging, mainly due to the insufficiency of biomarkers that distinguish EPSCs from other skin proliferative cells. Thus, it is essential to define methods and biomarkers to obtain well-characterized and specific EPSCs. As EPSCs have high integrin- $\beta 1$ expression and collagen IV supports fast adhesion of EPSCs through integrin- $\beta 1$, a relatively simple method for EPSC enrichment involves the incubation of cells on collagen IV for $20 \mathrm{~min}$, and more differentiated cells with lower expression of integrin- $\beta 1$ are rinsed away [10]. Fluorescence-activated cell sorting (FACS) is an efficient and widely used technique for EPSC selection [7]. Using FACS, EPSC enrichment can be achieved by sorting for high integrin $\beta 1$ expression $[10,11]$ and the combination of high expression of integrin $\alpha 6$ with low transferrin $\left(\alpha 6^{\text {high }} / D 71^{\text {low }}\right)$ [12]. Other cell surface biomarkers, including delta-like 1 (DLL1) [13], CD46 [14], immunoglobulin-like domain 1 (LRIG1) [15], keratins19/5/14, CD49f $\mathrm{f}^{\text {bri }} / \mathrm{CD} 71^{\mathrm{dim}}$ [16], Notch ligand, and leucine-rich repeats, have recently been identified and used in EPSC enrichment. Another FACS-based strategy for EPSC enrichment is sorting for cells that maintain the export of Hoechst dye [17].

In addition to isolating EPSCs from skin tissues, EPSCs can be generated from induced pluripotent stem cells (iPSCs) [18]. iPSCs, which share similar features to embryonic stem cells, can be obtained from adult somatic cells, including fibroblasts, keratinocytes, lymphocytes, and liver cells $[19,20]$ by exogenous addition of specific transcription factors, such as Sox2, Oct-3/4, cMyc, and Klf4 using retroviral transduction. Recent studies have reported that EPSCs can be generated from human CD200+ and ITGA6+ iPSCs and can reconstitute hair follicle lineages and the interfollicular epidermis [21].

\section{Expansion of EPSCs in vitro}

Cell culture is essential in stem cell-based tissue engineering and regenerative medicine. Several research groups have attempted to culture human epidermal cells, including EPSCs since the early 1960s; however, researchers failed to expand and subculture isolated EPSCs in vitro. Currently, the Rheinwald and Green method is the most widely used culture system for EPSCs, which allows massive expansion and progressive growth of colonies of cells by co-culturing EPSCs with mitotically inactivated feeder cells [22]. 3T3-J2 cells, which are a subclone of the original 3T3 line, are usually used as feeder cells, and mitomycin-C is used to treat feeder cells, which covalently cross-links double-stranded DNA and prevents the separation of DNA strands during replication [23]. In addition, the culture medium is improved by the addition of cholera toxin, adenine, triiodothyronine, epidermal growth factor, and adenine [23]. However, as the Rheinwald and Green culture method contains murine fibroblasts and fetal bovine serum, the transmission of microbes from animals is the potential risk, limiting its widespread application. To avoid this potential risk, chemically defined culture media without animal-derived ingredients have been developed and are commercially available [24]. These feeder- and serum-free media [25] enable clonal growth and serial culture of EPSCs, but it is still unclear whether they can maintain EPSCs for long periods ex vivo.

Recently, the components of the basement membrane, recombinant laminins LN-511 and LN-421, were used to replace murine 3T3 feeder cells [26], and this laminin culture system can be comparable to the murine cell coculture systems in terms of colony-forming efficiency, gene expression, the capacity to form epidermis, and long-period maintenance of regenerated epidermis after transplantation, providing a new platform for EPSCs research and safer stem cell therapy. Furthermore, small chemical molecules, such as DMH-1 and A-83-01 (SMAD inhibitors) [27], RepSox (TGFßRI/ALK5 inhibitor) [28], DAPT (g-secretase inhibitor) [29], and Y27632 (Rho-kinase inhibitor) [30, 31], are intracellular signaling inhibitors that can promote the expansion and proliferation of cultured EPSCs. The combination of serum- and feeder-free media with small molecules provides a new platform for EPSCs research and safer stem cell therapy.

Furthermore, new studies have attempted to utilize a three-dimensional (3D) culture system to mimic the stem cell niche that is important for EPSCs to maintain homeostasis. A 3D micronized (300-600 mm) amniotic 
membrane (mAM) was reported to retain the basement membrane structure and contain growth factors such as nerve growth factor (NGF), basic fibroblast growth factor (bFGF), hepatocyte growth factor (HGF), epidermal growth factor (EGF), and transforming growth factor- $\beta 1$ (TGF- $\beta 1$ ) [32]. EPSCs expanded quickly and maintained the characteristics of stem cells when cultured in the $\mathrm{mAM}$, and the mAM with EPSCs gradually developed into a new epidermis when transplanted onto mice with full-thickness skin wounds [32].

\section{Tools to study EPSCs}

\section{Genetic lineage tracing}

Lineage tracing can identify the progeny of a single cell, proving the information of the number of all progeny of the founder cells and their differentiation status and location. As a crucial tool for studying the properties of stem cells, lineage tracing gives us information about how the stem cells behave in different organism.

The Cre-loxP system is usually used for genetic lineage tracing in mice [33, 34], which can genetic label stem cells in the tissue [35]. A transgenic mice expressing Cre recombinase fused to a mutated estrogen receptor expressed under the control of the epidermal basal layer-specific keratin 14 promoter was observed [36]. This mice line was crossed with a second mice line in which a reporter was flanked by a loxP-STOP-loxP ("floxed" STOP) sequence [37]. In mice that expressed both constructs, Cre recombines the loxP sites, excising the STOP sequence and activates LacZ expression genetically in the K14+ cells. The recombined and LacZ reporter is passed onto their progeny when these cells divide. By detecting $\beta$-galactosidase, the label can be observed [36]; however, $\beta$-galactosidase has its deficiencies because it cannot be tested in live cells by flow cytometry. The first fluorescent reporter mice are expressing enhanced GFP [38], and subsequently, other fluorophores are used, including tdTomato [39], enhanced yellow fluorescent protein, and multicolor confetti [40].

\section{Skin reconstitution assay}

EPSCs are characterized by the capacity to self-renew and the ability to produce different differentiated cells in tissues, which are evaluated using the skin reconstitution assay [41]. Using this assay, the wound repair and reconstitution from disaggregated cell populations can be assessed [42]. In addition, compared to the lineage tracing, multiple parameters can be assessed and multilineage differentiation can be evaluated in a shorter time and using much fewer mouse. Several different methods for in vivo reconstitution of the epidermis have been investigated, such as seeding cells in a chamber between the epidermis and dermis [43] or seeding cells onto scaffolds [44]. The skin reconstitution assay not only allows clonal analysis, but also facilitates assessment of capacity of EPSCs to generate progeny and self-renew.

\section{Label retention}

Stem cells including EPSCs are noted for their infrequent division (slow cycling) and relative quiescence. Since EPSCs are characterized by differential history of cell division, it could be distinguished from cells that divide frequently. As label-retaining cells (LRCs), EPSCs can retain radioactively-labeled nucleotides, such as thymidine analogs, tritiated thymidine, and 5-bromo-2'deoxyuridine (BrdU) $[45,46]$. The most commonly used DNA-label method is the BrdU pulse-chase method. The dividing cells can be marked and their division history can be followed by using this method [47]. As a pyrimidine analog of thymidine, BrdU can incorporate into DNA during DNA synthesis process. Once BrdU is injected onto mouse, cells that replicate during the pulse stage will be labeled. In the following "chase" stage, the frequently dividing cells lose most of their incorporated BrdU label after division, and EPSCs will keep the BrdU marker $[46,48]$. However, the main disadvantage of this method is that some post-mitotic terminally differentiated cells will keep DNA markers efficiently and stay in the organs $[49,50]$. Alternatively, to isolate and visualize LRCs, the pulse-chase technique and green fluorescent protein (GFP) tagged histone H2B (H2B-GFP) were used, which are expressed in specific tissues and tetracyclinedependent [51]. Currently, the tet-controllable transgenic mouse that expressed H2B-GFP has been used to mark and chase EPSCs [51]. This approach has now been used extensively as it can label quiescent cells completely, because of the earlier expressed H2B-GFP and relative longer pulse duration. Label-tracing experiments were performed not only in rodent models, but also in human cells $[52,53]$, showing that EPSCs are a state of slow cycle in vivo; however, when EPSCs are released from quiescence, they are capable of long-term proliferation and selfrenewal [54].

\section{Clonogenic assays}

Isolating cells from organs and culturing isolated cells in vitro is the earliest method used to identify EPSCs. Examination of the ability of clonal growth of individual cells can give us a quantitative read-out of EPSCs number and has been used to evaluate potential markers of EPSCs. Stratified epidermal cell sheets were formed by a subpopulation of proliferated cells, which form large colonies and at confluence [22]. The conditions for culturing EPSCs have been improved to enable the cultures to be used as autografts for the treatment of burn wounds, demonstrating that stem cells can survive in culture $[55,56]$. The proliferative ability of primary epidermal cells are evaluated by culturing them at clonal 
density and then subcloned; three types of clones were identified [57], which prompted an attempt to identify the basis of their growth characteristics in vitro. One type of clone is termed "holoclones," which are large circular colonies that generate more than $10^{16}$ cells when subcloned and have the capability of high proliferative potential and self-renew. The second type is termed "paraclones," which are small and irregularly shaped clones. These cells do not have high proliferative potential generating new colonies and own the properties similar to transit amplifying cells. The third type of colony is called "meroclones," which have proliferative ability and an appearance intermediate between paraclones and holoclones [57], demonstrating that not all basal cells in the epidermis have the same proliferative potential in vitro. In addition to these three identified types of clones, other detections for clonal growth have been employed, such as one in which the proportion of "abortive colonies" was scored. Abortive colonies obtain the features of transit amplifying cell founders; however, the clones that can self-renew actively obtain the features of stem cells $[10,58,59]$. When the proportion of putative stem cells is expanded, the proportion of cells that undergo terminal differentiation is unaltered [59].

\section{Interaction between EPSCs and the dermis}

The heterogeneity and compartmentalization of EPSCs have been considered key features in epidermal homeostasis. As EPSCs existed in the basal layer of the epidermis are exposed to different types of dermal cells, including fibroblasts, adipocytes, muscle cells, neuronal cells, and melanophores, the previously unappreciated role of EPSCs as a niche for neighboring dermal cells has been highlighted recently [60]. The temporally and spatially specialized epidermal-dermal units play important roles in the development, function, homeostasis, repair, and regeneration of skin tissue.

\section{EPSC-fibroblast unit}

As well-characterized fibroblast populations, dermal papilla located at the base of each hair follicle and close to the basement membrane communicates with the neighboring epidermis and provides essential signals for hair follicle morphogenesis and regeneration [61-63]. As dermal papilla cells constantly attach to the hair germ epidermis, which contains EPSCs including shorter-lived transit amplifying cells and long-lived stem cells, thus, information from the epidermal layer are important for the activation and maintenance of dermal papilla (Fig. 1a). The transcriptional repressor Blimp1 and canonical Wnt signaling are key mediators of this interaction [63-65]. For example, upon induction of hair follicles during development, epidermal $\mathrm{Wnt} / \beta$-catenin signaling induces Blimp1 expression in the dermal papilla fibroblasts through transforming growth factor (TGF) $\beta$ signaling. In the dermal papilla, Blimp1 activates $\mathrm{Wnt} / \beta$-catenin signaling and hair follicle stem cellmediated hair follicle growth [66]. In addition, when the dermal papilla matures during hair follicle growth, the heterogeneity of mesenchymal signals including Wnt ligand gradients and bone morphogenetic protein (BMP) inhibitors creates distinct micro-niches along the epidermal-fibroblast interface in the dermal papilla [67]. Different basal cells in distinct epidermal structures can provide microenvironments to maintain and induce dermal fibroblast diversity; other epidermal appendages, including sweat glands, sebaceous glands, and nails also have different fibroblast populations under the epidermal layer, and further research is needed to clarify their characteristics and interactions [68].

\section{EPSC-muscle unit}

A smooth muscle called the arrector pili muscle (APM) is involved in the association between the epidermis and the adjacent mesenchyme. APM is responsible for piloerection to trap warm air at the skin surface and thus plays an essential role in the thermoregulation. Piloerection also induces contraction of the sebaceous glands, enabling release of sebum onto the skin surface [69]. Hair follicle bulge is the permanent attachment site of the APM [70, 71] (Fig. 1b). The bulge containing EPSCs has been reported to construct a specific niche that facilitates the attachment of EPSCs to the hair follicle bulge and the development of APM [70]. During follicle development, bulge stem cells deposit a number of extracellular matrix (ECM) proteins onto the underlying basement membrane. Nephronectin is one of them, which is an ECM protein with five EGF-like repeats, a $\mathrm{COOH}$-terminal MAM domain, and an RGD sequence [72]. As an important mediator of epidermal interactions with mesenchymal cells, nephronectin is specifically recognized by $\alpha 8$ integrin in dermal muscle precursors, promoting the differentiation of them and correct attachment to the bulge [72-74]. Detection of $\alpha 8$ integrin or nephronectin causes delocalization and reduced formation of the APM. In addition, research has shown that genes related to the formation of tendon/ligament are highly overrepresented in bulge EPSCs [70]. As the tendon or cartilage is aneural, avascular, and low-proliferative in the hair follicle bulge, extrinsic characteristics and tendon-like intrinsic in the bulge can explain the quiescent feature of bulge EPSCs.

\section{EPSC-adipocyte unit}

Studies have shown that the oscillation in the dermal adipocyte layer and the growth cycle of hair follicle are 


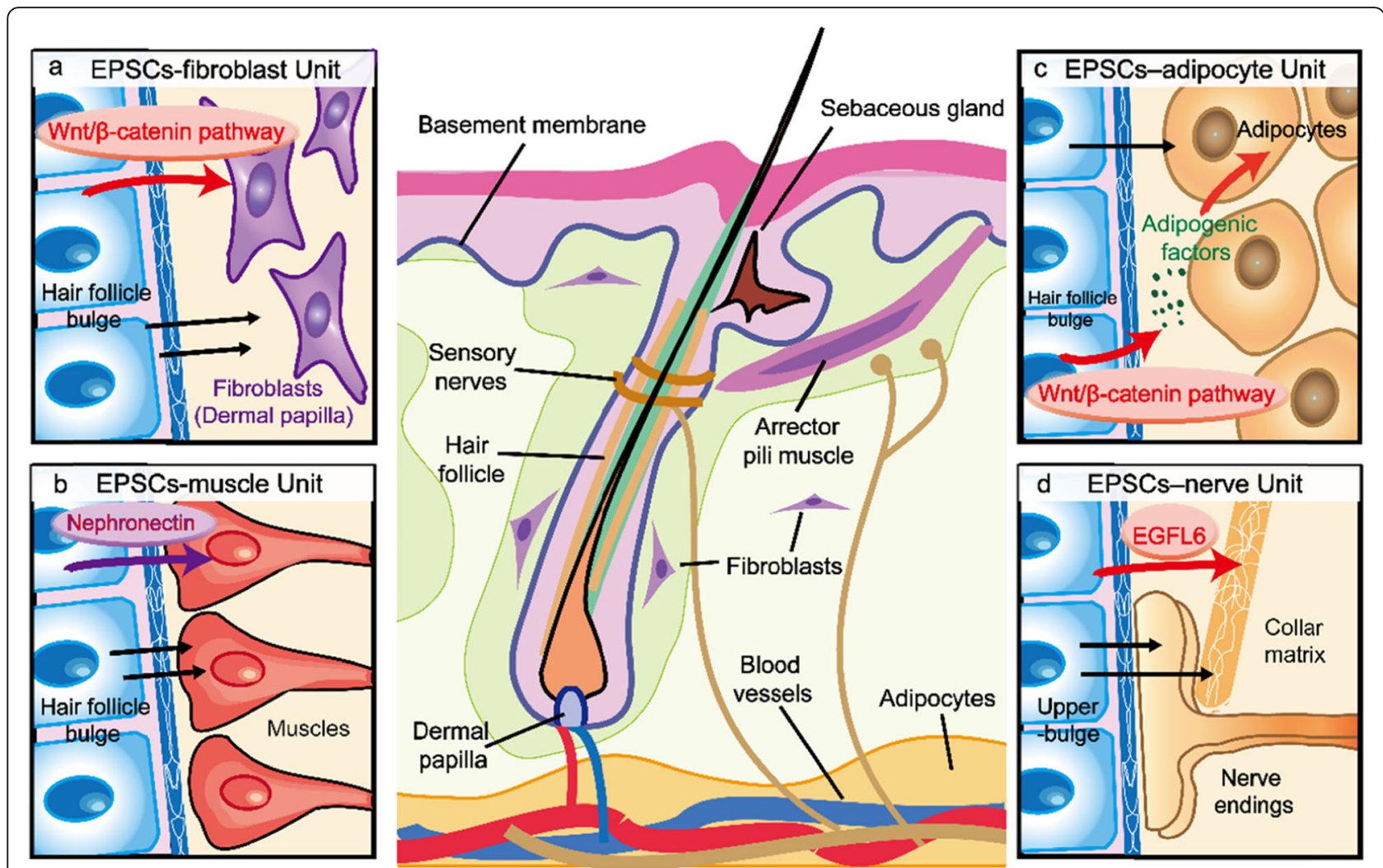

Fig. 1 The interaction between EPSCS and the dermis. a The EPSC-fibroblast unit. b The EPSC-muscle unit. $\mathbf{c}$ The EPSC-adipocyte unit. d The EPSC-nerve unit. This image is based on a previously published image [60]

synchronized [75]. In the anagen (growth) phase, the thickness of the adipocyte layer increases because of the hypertrophy of individual adipocytes and increased adipogenesis. In the catagen (regression) and telogen (resting) phase, hair follicles regress and the adipocyte layer becomes thinner [76]. Studies have shown that activation of the epidermal $\mathrm{Wnt} / \beta$-catenin pathway correlates with the synchronized pattern of growth of hair follicle and expansion of the dermal adipocyte layer [77, 78] (Fig. 1c). Activation of epidermal Wnt pathway causes the secretion of adipogenic factors such as IGF signaling pathways and ligands of BMP [79]. Therefore, EPSCs produce transit amplify (TA) cells through Wnt signaling which are located at the bottom of the hair follicles, restricting the adipogenesis niche that reside at the lower part of the skin. However, activation of $\beta$-catenin pathway across the epidermal basal layer will lead to an extensive increase in adipocytes and failure in the development of hair follicle throughout the dermis [75]. Therefore, spatiotemporal activation of Wnt signaling in EPSCs provides an adipogenic niche in the lower part of the dermis, orchestrating the regeneration of two distinct cellular lineages during skin wound repair.

\section{EPSC-nerve unit}

As the largest sensory organ in the human body, skin epidermis is innervated by different types of sensory nerves, which constitute a variety of mechanosensory end organ structures, such as Merkel cell-neurite complexes, hair follicle lanceolate complexes, and free nerve endings [80]. Lanceolate complexes, which consist of various non-cellular and cellular ingredients and form the collars of mechanoreceptor terminals, such as the terminal Schwann cell processes and parallel, longitudinally aligned low-threshold mechanoreceptor (LTMR) axonal endings [81], are exits in the upper bulge of the hair follicle, where Gli1-positive upper-bulge EPSCs reside [82-84] (Fig. 1d). As a sensory end organ, lanceolate complexes are very important in encoding several touch signals [85]. Studies have shown that EPSCs in the upper bulge of the follicle express a unique set of neurogenesis and ECM-related genes [86]. EPSCs deposit EGFL6, which is a kind of ECM protein, into the collar matrix. EGFL6 tightly ensheathes lanceolate complexes at the caudal side of the hair follicle. EGFL6 is essential for the touch responses, $\alpha v$ integrin enrichment of lanceolate complexes, and proper patterning. BDNF that derived from follicle EPSCs is essential for interactions of 
follicle-nerve, which is increased in the upper-bulge epidermis, and its deficiency destroys caudally polarized distribution of A $\delta$-LTMR lanceolate endings [84]. In addition, the EPSC-created epidermal tissue architecture also plays an important role in the formation, preservation, and function of the epidermal-nerve unit. The first bulge structure, which is established during follicle morphogenesis, is kept as an old bulge at the caudal side of the hair follicles, which provides a structurally stable niche for epidermal-nerve interaction and induces a lanceolate complex structure oriented toward the caudal side of the hair follicle [86].

\section{EPSCs in skin tissue engineering}

Combining biomaterial scaffolds with stem cells is a potential strategy for engineering tissues, delivery of cells, and regeneration of native organs [8,9]. Potential scaffold materials are classified as natural, such as collagens, hyaluronan, chitosan, silks, elastins, alginates, and fibrins [87, 88], and synthetic polymers including polyanhydrides, poly (lactic-co-glycolic) acid (PLGA), and polyethylene glycol (PEG) (Table 1). There are structural or functional classifications, such as whether they are injectable, hydrogels, surface modified capable of medicine delivery, by specific application. The most important characteristics critical to the success of biomaterial scaffolds are bioactivity, biodegradability, and biocompatibility [87]. These scaffolds suggest possibility for application of tissue engineering and could be used as substitutions for impaired organs. These scaffolds facilitate the differentiation and viability of stem cells seeded inside-based on both the incorporation of specific cues into the material and the intrinsic properties of the material.

\section{Natural biomaterials}

It is advantageous to use natural biopolymers in biomedical applications, as these materials contain sites for cellular adhesion, they do not release cytotoxic degradation products, and the degradation rates of natural biopolymers can be manipulated [89]. Thus, many recent in vivo studies and the Food and Drug Administration (FDA) approval of new biomaterials for clinical use have utilized natural biopolymers as matrices for delivery of stem cells.

\section{Protein-based biomaterials}

Protein-based scaffolds can provide appropriate structure in human tissues, which are applicable for tissue engineering involving the growth, differentiation, and transplantation of stem cells. As one of the major ECM-based proteins, collagen has been widely used for stem cell delivery in vivo. A recent study has reported that leucine-rich repeat-containing G-protein coupled receptor 6 (LGR6+) EPSCs are able to undergo proliferation, differentiation, and migration following seeding onto collagen-based scaffolds. These EPSC-containing collagen scaffolds are capable of repairing full-thickness wounds and hair regeneration [90]. Fibrin is a fibrinogen-derived protein, which has been used as a sealant in clinical researches and as a potential scaffold material for stem cell growth and delivery. Fibrin-based human skin substitute containing epidermal or dermal cells can result in good healing of massive full-thickness burn wounds. Another important ECM-based biomacromolecule is elastin, which has also been used in a variety of applications of tissue engineering, including in the form of tropoelastin [91, 92]. In addition, scaffolds made of silk have slow degradation rates and desirable mechanical properties, making it attractive for

Table 1 Scaffold materials in the tissue engineering

\begin{tabular}{|c|c|c|c|}
\hline Biomaterials & Examples & Structure & Application \\
\hline \multirow[t]{4}{*}{ Natural biomaterials } & Elastin & An elastic protein made up of water soluble tropoelastin & $\begin{array}{l}\text { Cardiac stent coatings, soft tissue reconstruction, } \\
\text { orthopedics }\end{array}$ \\
\hline & \multirow[t]{2}{*}{ Collagen } & A fibrous triple-helical protein & \multirow{2}{*}{$\begin{array}{l}\text { Wound healing, skin grafts, muscle repair, nerve } \\
\text { regeneration, anti-aging }\end{array}$} \\
\hline & & $\begin{array}{l}\text { Collagen type I, a major subtype consists of two alpha } \\
1 \text { units and one alpha } 2\end{array}$ & \\
\hline & Chitosan & $\begin{array}{l}\text { A linear polysaccharide consisting of } \beta \text {-(1-4)-linked } \\
\text { D-glucosamine and } N \text {-acetyl-D-glucosamine }\end{array}$ & $\begin{array}{l}\text { Wound healing, orthopedics, cardiac repair, } \\
\text { nerve regeneration, drug and gene delivery }\end{array}$ \\
\hline \multirow[t]{2}{*}{$\begin{array}{l}\text { Protein-based } \\
\text { biomaterials }\end{array}$} & Fibrin & $\begin{array}{l}\text { A fibrous non-globular protein produced by the cleavage } \\
\text { of fibrinogen }\end{array}$ & Wound healing, cardiac repair, cell delivery \\
\hline & Silk & $\begin{array}{l}\text { Extracted from cocoon of silk worms. It contains fibrous } \\
\text { protein fibroin and water soluble sericin protein }\end{array}$ & $\begin{array}{l}\text { Muscle repair and regeneration, bone tissue } \\
\text { engineering, cornea repair, drug delivery }\end{array}$ \\
\hline $\begin{array}{l}\text { Polysaccharide-based } \\
\text { biomaterials }\end{array}$ & Alginate & $\begin{array}{l}\text { An anionic polysaccharide consisting of homopolymeric } \\
\text { blocks of (1-4)-linked } \beta \text {-D-mannuronate }(\mathrm{M}) \text { and } \mathrm{C}-5 \\
\text { epimer a-L-guluronate (G) residues }\end{array}$ & $\begin{array}{l}\text { Wound healing, drug delivery, soft tissue, } \\
\text { engineering, cell delivery, in vitro stem cell } \\
\text { maintenance }\end{array}$ \\
\hline $\begin{array}{l}\text { Synthetic polymer- } \\
\text { based biomaterials }\end{array}$ & $\begin{array}{l}\text { Poly-L-lactic acid } \\
\text { (PLLA) and PLGA }\end{array}$ & $\begin{array}{l}\text { Copolymers that consist of monomers of lactic acid } \\
\text { and glycolic acid connected by ester bonds }\end{array}$ & Wound healing, cell delivery \\
\hline
\end{tabular}


tissue engineering applications. Scaffolds made from silk fibers can be fabricated into various structures, and silk can also be chemically modified. Stem cells, such as mesenchymal stem cells (MSCs), EPSCs, and adiposederived stem cells (ASCs) combined with silk scaffolds can be successfully used in skin tissue engineering to enhance wound repair and regeneration $[93,94]$.

\section{Polysaccharide-based biomaterials}

Polysaccharides, which are obtained from animal or plant sources and consist of sugar monomers, serve as a potential scaffold material for stem cell transplantation. One of the specific properties of polysaccharides is that they can rapidly be formulated into a gel, allowing them to be directly injected into injury sites. The use of polysaccharide-based scaffolds for the culture, differentiation, and delivery of stem cells in tissue engineering has been increasingly emphasized recently. Agarose, which consists of a galactose-based backbone, has been used as a scaffold in combination with stem cells in a variety of applications. Agarose scaffolds are appropriate for stem cell differentiation, providing a universal platform for tissue engineering [95]. Alginate, another polysaccharide, is derived from the cell walls of brown algae and can form scaffolds by ionic cross-linking, allowing the encapsulation of cells. Alginate scaffolds have also been used in combination with stem cells, such as adipose-derived adult stem cells and adult neural progenitor cells for repairing cartilage and spinal cord injuries [96, 97]. A recent study has also demonstrated that the viability, proliferation, and lineage differentiation of EPSCs are enhanced when they are encapsulated in alginate scaffolds [98, 99], and alginate can be used as an ideal bioink ingredient in stem cell-laden 3D bioprinting [100].

\section{Synthetic polymer-based biomaterials}

Although natural biomaterials have been widely used in stem cell-based tissue engineering, these natural materials have some disadvantages, including a high risk for pathogen contamination, high lot-to-lot variability, and difficult sterilization and purification. In addition, these natural scaffolds have limited mechanical properties and need to be improved for stem cell culture [101, 102]. Synthetic biomaterials provide an alternative to natural materials to be used in stem cell culture. The defined chemical composition of these materials offers many advantages including reproducibility, controllable mechanical properties, and degradation rate. Therefore, a variety of synthetic biomaterials has been used for applications of different tissue engineering [87].

Poly-L-lactic acid (PLLA) and PLGA are copolymers that consist of monomers of lactic acid and glycolic acid connected by ester bonds. As approved polymers, PLLA and PLGA have been used in tissue engineering applications because of their ability to modulate the degradation rate and the biocompatibility. Scaffolds made using PLGA or PLLA were used to deliver stem cells to wounds, which can promote wound healing by enhancing the differentiation of stem cells [103, 104]. PEG is another biodegradable synthetic polymer that has been used for regenerative applications due to its high molecular weight and the ability to resist protein absorption. In combination with stem cells, PEG scaffolds have been widely used for their suitability as replacements for skin, cartilage, bone, liver, vasculature, and nerve tissues.

\section{D bioprinting}

3D printing technologies have been used to cells, supporting components, and biocompatible materials, giving a great promise for artificial organ and tissue printing (Fig. 2). Much of the 3D bioprinting research has been focused on reconstruction of human cartilage and bone tissues. More recently, there has been research into skin biofabrication using 3D bioprinting technology, which involves the use of deposition of stem cells, which was controlled by computer, into precise 3D geometrical patterns $[105,106]$. Scaffold-based tissue engineering methods by cultivating and seeding stem cells in bioactive scaffolds have been widely used in reconstruction of skin. However, the deficiencies in these methods, such as lack of accurate delivery of cells, can be overcome by the use of stem cells combined with 3D bioprinting technology. Furthermore, the application of stem cells in the $3 \mathrm{D}$ printed constructs allow the introduction of various cell types with positional specificity [107]. The ability to "print" functional skin tissue successfully depends largely on the cell and biomaterial used. Similar to the bioink, the biomaterials should possess specific characteristics, including biocompatibility, biodegradability, bioinertness, strength, durability, and ductility [108]. These biomaterials are "printable," which are determined by two characteristics: rheology and cross-linking abilities [109]. Therefore, the biomaterials used in 3D bioprinting are classified as natural polymers, including chitosan, collagen and fibrinogen, or synthetic polymers, including polycaprolactone and PLGA $[110,111]$. In addition, cell selection is the second key component, and stem cells such as EPSCs have been identified as an ideal alternative as they have the ability of self-renewal and multiple differentiation potential [112]. Currently, the commonly used 3D bioprinting methods range from inkjet bioprinting, laser-assisted bioprinting, and extrusion bioprinting to much more advanced technologies including scaffold-free spheroid-based bioprinting [113]. For example, using the extrusion bioprinting method, cell-laden 3D-ECM mimics were bioprinted in vitro by using sodium alginate hydrogels and composite gelatin, which allowed for the EPSCs differentiation into sweat 


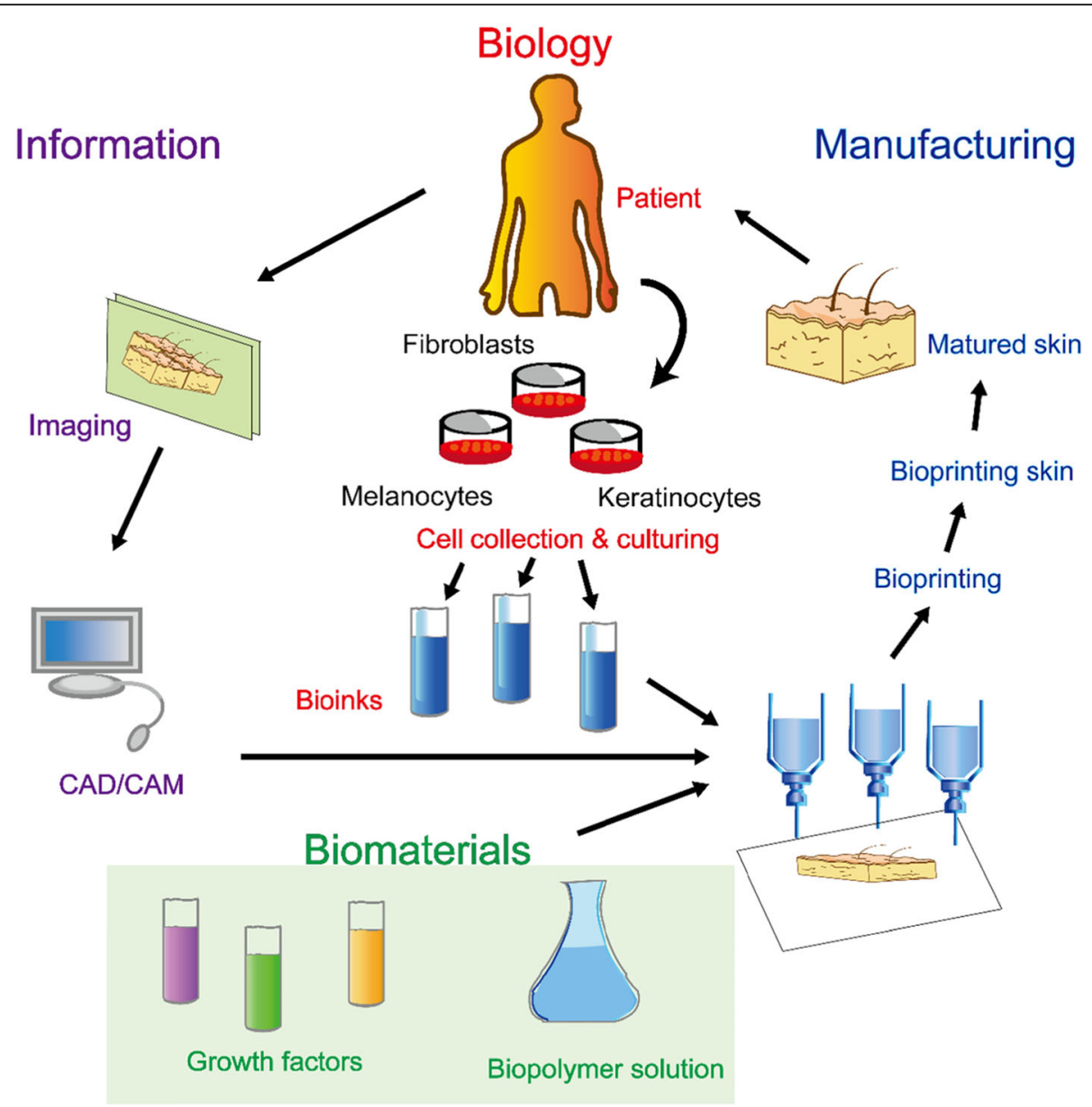

Fig. 2 Steps in the fabrication of 3D bioprinted skin

glands, and application of this bioprinted construct into skin wounds induces the reconstruction of sweat glands [114]. In addition, full-thickness skin equivalents have also been printed using the 3D inkjet bioprinting method combined with epidermal and dermal cells, with clinical and translational implications [115].

It is tangible to the application of 3D bioprinting in the wound repair and skin regeneration. The potential applications in dermatology are bioprinting skin models to test new treatments for diseases including atopic eczema [110], psoriasis, and vitiligo [116] and studying the pathophysiological mechanisms of skin wounds [117].

\section{FDA-approved products}

Several tissue-engineered biological wound dressings have been approved by FDA. For example, Apligraf", which was proved by FDA in 1998, is made from a bilayer structure, which contains a monolayer of keratinocytes at the outer layer and fibroblasts at the inner layer. As a living cell therapy, Apligraf delivers the proteins produced by the cells and collagen and serves as a valuable therapeutic strategy for skin wounds, such as nonhealing venous leg ulcers (VLU) and diabetic foot ulcers (DFU) [118]. As a sister product of Apligraf , GINTUIT $^{\circ}$ is a keratinocyte fibroblast-containing sheet, which is the first FDA-approved cell therapy product for wound healing in the oral soft tissue defects [119]. Similar to Apligraf, keratinocytes in GINTUIT ${ }^{\bullet}$ improve structural strength and fibroblasts provide the growth factors and the cytokine secretion effective on wound treatment through a bovine collagen matrix structure.

\section{Adipose-derived stem cells (ASCs) in skin tissue engineering}

Studies have shown that ASCs not only can be used as a therapeutic method in personalized medicine to assess safety and efficacy of the breast reconstruction, but also have a potential usefulness in neurodegenerative conditions [120]. In addition, the fat graft enhanced with adipose-derived stem cells (FG-e-ASCs) has been widely used in repaired treatment of ulcers and breast tissue defects and breast augmentation [121]. Recently, engineered fat graft enhanced with adipose-derived stromal vascular fraction cells (EF-e-A) has been demonstrated as a reliable alternative to breast implant and used in 
breast reconstruction [122]. ASCs are recognized to promote wound healing through the inhibition of inflammation, promoting angiogenesis. Recent studies revealed that adipocyte-secreted exosomal microRNA (A-SE-MiR) also plays an important role in ASC-based therapies [123].

Autologous fat grafts have many clinical applications, such as facial rejuvenation, breast surgery, buttock augmentation, and Romberg syndrome. The stromal vascular cell fraction (SVF) of the adipose tissue provides a rich source of multipotent adipose tissue-derived stromal cells. The combined use of SVF/ASCs in fat grafting and platelet-rich plasma (PRP) is effective in the treatment of scars on the face, breast reconstruction, and chronic ulcers $[124,125]$. PRP can release growth factors and hormones, representing an alternative strategy in wound repair and tissue regeneration. Clinically, PRP with or without Hyalomatrix PA (HPA) serves as new therapeutic strategies in the treatment of hidradenitis suppurativa, complex wound with bone exposure, and hair loss [124, 125]. In the treatment of hair loss, in addition to PRP, the use of stem cells, such as human follicle stem cells (HFSCs) and Human Intra- and Extra-Dermal Adipose Tissue-Derived Hair Follicle Stem Cells (HD-AFSCs), represents safe and effective therapies [126-128]. The activity of Wnt signaling in dermal papilla cells is important in enhancing growth of hair. In addition, signaling from platelet-derived growth factors and mesenchymal stem cells influences hair growth through cellular proliferation to prolong the anagen phase by FGF-7, stimulating development of hair follicle by $\beta$-catenin and cell growth by ERK activation, and suppressing apoptosis by Akt activation and Bcl-2 release $[129,130]$.

\section{Conclusions and perspectives}

The currently used therapeutic strategies for skin repair are skin grafts and skin substitutes; however, there is still a lack of comprehensive treatment that emulates the complex regenerative process. As an ideal therapeutic product, the advanced bioengineered skin grafts containing EPSCs combined with biomaterials can efficiently support repair and regeneration of skin wounds. However, there are still many limitations on their experimental and clinical applications, for example, they are still expensive to manufacture, the skin appendices are usually not regenerated, and the experimental results of in vivo studies using rodents are only partially comparable to humans. Advanced stem cell research and tissue engineering approaches may provide solutions to these issues in the future. In addition to overcoming the difficulty of enrichment of renewable source of EPSCs in large quantities, major advances in both knowledge of the biology of EPSCs and the development of tissue engineering scaffolds will finally allow the widespread application of EPSC-based tissue-engineered skin for tissue repair and regeneration.

\section{Abbreviations}

EPSCs: Epidermal stem cells; FACS: Fluorescence-activated cell sorting; 3D: Three-dimensional; DLL1: Delta-like 1; LRIG1: Immunoglobulin-like domain 1; iPSCs: Induced pluripotent stem cells; mAM: Micronized amniotic membrane; NGF: Nerve growth factor; bFGF: Basic fibroblast growth factor; HGF: Hepatocyte growth factor; EGF: Epidermal growth factor; TGF$\beta 1$ : Transforming growth factor- $\beta 1$; LRCs: Label-retaining cells; BrdU: 5 Bromo-2'-deoxyuridine; GFP: Green fluorescent protein; TGF: Transforming growth factor; BMP: Bone morphogenetic protein; APM: Arrector pili muscle; ECM: Extracellular matrix; TA: Transit amplify; LTMR: Low-threshold mechanoreceptor; PLGA: Poly (lactic-co-glycolic) acid; PEG: Polyethylene glycol; FDA: Food and Drug Administration; MSCs: Mesenchymal stem cells; PLLA: Poly-L-lactic acid

\section{Authors' contributions}

$R H Y, J L X$, and $K X$ designed the experiment. RHY and SY drafted the manuscript. RHY and XMJ drew the figures, KX, JLZ, XDC, and JRW participated in modification of the paper. The authors read and approved the final manuscript.

\section{Funding}

This study was supported by the National Natural Science Foundation of China (Nos. 81671970, 81772136, 81871566, 81772134, 81971891, 81571939), the Key Research and Development Program of Hunan Province (No. 2018SK2091), Wu Jie-Ping Medical Foundation of the Minister of Health of China (No. 320.6750.14118), Foundation of Foshan City (grant numbers 2017AG100181, FSOAA-KJ218-1301-0034, 2018AB003411), Science and Technology Planning Project of Guangdong Province (grant numbers 2017ZC0466), and Guangzhou Science and Technology Project (grant numbers 2018-0402-SF-0686).

\section{Availability of data and materials}

Data sharing is not applicable to this article as no datasets were generated or analyzed during the current study.

\section{Ethics approval and consent to participate}

Not applicable.

\section{Consent for publication}

Not applicable.

\section{Competing interests}

The authors declare that they have no competing interests.

\section{Author details}

${ }^{1}$ Department of Burn Surgery, The First People's Hospital of Foshan, Foshan 528000, Guangdong, China. ${ }^{2}$ Department of Neurosurgery, The First Affiliated Hospital of Sun Yat-Sen University, Guangzhou 510080, Guangdong, China. ${ }^{3}$ Department of Burn Surgery, First Affiliated Hospital of Sun Yat-Sen University, Guangzhou 510080, Guangdong, China. ${ }^{4}$ Clinical Medicine Eight-year Program, 02 Class, 17 Grade, Xiangya School of Medicine, Central South University, Changsha 410013, Hunan, China. ${ }^{5}$ Department of Anatomy and Neurobiology, School of Basic Medical Science, Central South University, Morphological Sciences Building, 172 Tongzi Po Road, Changsha 410013, Hunan, China. ${ }^{6}$ Hunan Key Laboratory of Ophthalmology, Changsha 410008, Hunan, China.

Received: 20 May 2020 Revised: 19 June 2020

Accepted: 30 June 2020 Published online: 22 July 2020

\section{References}

1. Ohyama M, Terunuma A, Tock CL, Radonovich MF, Pise-Masison CA, Hopping SB, Brady JN, Udey MC, Vogel JC. Characterization and isolation of stem cell-enriched human hair follicle bulge cells. J Clin Investigation. 2006; 116:249-60. https://doi.org/10.1172/JCI26043 [PMID: PMC1323261.

2. Tiede S, Kloepper JE, Bodo E, Tiwari S, Kruse C, Paus R. Hair follicle stem cells: walking the maze. Eur J Cell Biol. 2007;86:355-76. https://doi.org/10. 1016/j.ejcb.2007.03.006 [PMID: 17576022.

3. Nagel S, Rohr F, Weber C, Kier J, Siemers F, Kruse C, Danner S, Brandenburger M, Matthiessen AE. Multipotent nestin-positive stem cells reside in the stroma of human eccrine and apocrine sweat glands and can 
be propagated robustly in vitro. PloS one. 2013;8:e78365. https://doi.org/10. 1371/journal.pone.0078365 [PMID: PMC3813437.

4. Bickenbach JR, Grinnell KL. Epidermal stem cells: interactions in developmental environments. Differentiation. 2004;72:371-80. https://doi.org/10.1111/j.14320436.2004.07208003.x [PMID: 15606496.

5. Bickenbach JR, Stern MM. Plasticity of epidermal stem cells: survival in various environments. Stem Cell Reviews. 2005;1:071-8. https://doi.org/10. 1385/scr:1:1:071 [PMID: 17132878

6. Yang R, Liu F, Wang J, Chen X, Xie J, Xiong K. Epidermal stem cells in wound healing and their clinical applications. Stem Cell Res Ther. 2019;10: 229. https://doi.org/10.1186/s13287-019-1312-z [PMID: PMC6664527.

7. Kumar S, Poojan S, Verma V, Verma MK, Lohani M. Rapid isolation of integrin rich multipotent stem cell pool and reconstruction of mouse epidermis equivalent. Am J Stem Cells. 2014;3:27-36 [PMID: PMC3960755, https:// www.ncbinlm.nih.gov/pubmed/24660112.

8. Asti A, Gioglio L. Natural and synthetic biodegradable polymers: Different scaffolds for cell expansion and tissue formation. Int J Artif Organs. 2014;37: 187-205. https://doi.org/10.530/ijao.5000307 [PMID: 24744164.

9. Hinderer S, Layland SL, Schenke-Layland K. ECM and ECM-like materials biomaterials for applications in regenerative medicine and cancer therapy. Adv Drug Deliv Rev. 2016;97:260-9. https://doi.org/10.1016/j.addr.2015.11. 019 [PMID: 26658243.

10. Jones PH, Watt FM. Separation of human epidermal stem cells from transit amplifying cells on the basis of differences in integrin function and expression. Cell. 1993;73:713-24. https://doi.org/10.1016/00928674(93)90251-k [PMID: 8500165.

11. Gao X, Nowak-Imialek M, Chen X, Chen D, Herrmann D, Ruan D, Chen ACH, Eckersley-Maslin MA, Ahmad S, Lee YL, Kobayashi T, Ryan D, Zhong J, Zhu J, Wu J, Lan G, Petkov S, Yang J, Antunes L, Campos LS, Fu B, Wang S, Yong Y, Wang X, Xue SG, Ge L, Liu Z, Huang Y, Nie T, Li P, Wu D, Pei D, Zhang Y, Lu L, Yang F, Kimber SJ, Reik W, Zou X, Shang Z, Lai L, Surani A, Tam PPL, Ahmed A, Yeung WSB, Teichmann SA, Niemann H, Liu P. Establishment of porcine and human expanded potential stem cells. Nat Cell Biol. 2019;21:687-99. https://doi.org/10. 1038/s41556-019-0333-2 [PMID: PMC7035105.

12. Li A, Simmons PJ, Kaur P. Identification and isolation of candidate human keratinocyte stem cells based on cell surface phenotype. Proc Natl Acad Sci U S A 1998; 95: 3902-3907. doi: https://doi.org/10.1073/pnas.95.7.3902. [PMID: PMC19935.

13. Lowell S, Jones P, Le Roux I, Dunne J, Watt FM. Stimulation of human epidermal differentiation by delta-notch signalling at the boundaries of stem-cell clusters. Curr Biol 2000; 10: 491-500. doi: https://doi.org/10.1016/ S0960-9822(00)00451-6. [PMID: 10801437.

14. Tan DW, Jensen KB, Trotter MW, Connelly JT, Broad S, Watt FM. Single-cell gene expression profiling reveals functional heterogeneity of undifferentiated human epidermal cells. Development 2013; 140: 1433-1444. doi: https://doi.org/10.1242/dev.087551. [PMID: PMC3596987.

15. Jensen KB, Watt FM. Single-cell expression profiling of human epidermal stem and transit-amplifying cells: Lrig1 is a regulator of stem cell quiescence. Proc Natl Acad Sci U S A. 2006;103:11958-11,963. https://doi. org/10.1073/pnas.0601886103 [PMID: PMC1567680.

16. Cerqueira MT, Frias AM, Reis RL, Marques AP. Interfollicular epidermal stem cells: boosting and rescuing from adult skin. Methods Mol Biol. 1879;2019: 101-10. https://doi.org/10.1007/7651_2018_146.

17. Dunnwald M, Tomanek-Chalkley A, Alexandrunas D, Fishbaugh J, Bickenbach JR. Isolating a pure population of epidermal stem cells for use in tissue engineering. Experimental Dermatol 2001; 10: 45-54. doi: https:// doi.org/10.1034/j.1600-0625.2001.100106.x. [PMID: 11168579.

18. Sugiyama-Nakagiri Y, Fujimura T, Moriwaki S. Induction of skin-derived precursor cells from human induced pluripotent stem cells. PloS one 2016; 11: e0168451. doi: https://doi.org/10.1371/journal.pone.0168451. [PMID: PMC5167543 PLOS ONE policies on sharing data and materials.

19. Aasen T, Raya A, Barrero MJ, Garreta E, Consiglio A, Gonzalez F, Vassena R, Bilic J, Pekarik V, Tiscornia G, Edel M, Boue S, Izpisua Belmonte JC. Efficient and rapid generation of induced pluripotent stem cells from human keratinocytes. Nat Biotechnol. 2008;26:1276-84. https://doi.org/10.1038/nbt 1503 [PMID: 18931654

20. Aoi T, Yae K, Nakagawa M, Ichisaka T, Okita K, Takahashi K, Chiba T, Yamanaka S. Generation of pluripotent stem cells from adult mouse liver and stomach cells. Science 2008; 321: 699-702. doi: https://doi.org/10.1126/ science.1154884. [PMID: 18276851.
21. Yang R, Zheng Y, Burrows M, Liu S, Wei Z, Nace A, Guo W, Kumar S, Cotsarelis G, Xu X. Generation of folliculogenic human epithelial stem cells from induced pluripotent stem cells. Nat Commun 2014; 5: 3071. doi: https://doi.org/10.1038/ncomms4071. [PMID: PMC4049184.

22. Rheinwald JG, Green H. Serial cultivation of strains of human epidermal keratinocytes: the formation of keratinizing colonies from single cells. Cell 1975; 6: 331-343. doi: https://doi.org/10.1016/s0092-8674(75)80001-8. [PMID: 1052771.

23. Hynds RE, Bonfanti P, Janes SM. Regenerating human epithelia with cultured stem cells: feeder cells, organoids and beyond. EMBO Mol Med 2018; 10: 139-150. doi: https://doi.org/10.15252/emmm.201708213. [PMID: PMC5801505.

24. Boyce ST, Ham RG. Calcium-regulated differentiation of normal human epidermal keratinocytes in chemically defined clonal culture and serum-free serial culture. The Journal of investigative dermatology 1983; 81: $33 \mathrm{~s}-40 \mathrm{~s}$, doi: https://doi.org/10.1111/1523-1747.ep12540422. [PMID: 6345690.

25. Boonekamp KE, Kretzschmar K, Wiener DJ, Asra P, Derakhshan S, Puschhof J, Lopez-Iglesias C, Peters PJ, Basak O, Clevers H. Long-term expansion and differentiation of adult murine epidermal stem cells in $3 \mathrm{~d}$ organoid cultures. Proc Natl Acad Sci U S A 2019; 116: 14630-14,638. doi: https://doi.org/10. 1073/pnas.1715272116. [PMID: PMC6642409.

26. Tjin MS, Chua AWC, Moreno-Moral A, Chong LY, Tang PY, Harmston NP, Cai Z, Petretto E, Tan BK, Tryggvason K. Biologically relevant laminin as chemically defined and fully human platform for human epidermal keratinocyte culture. Nat Commun 2018; 9: 4432. doi: https://doi.org/10. 1038/s41467-018-06934-3. [PMID: PMC6207750.

27. Mou H, Vinarsky V, Tata PR, Brazauskas K, Choi SH, Crooke AK, Zhang B, Solomon GM, Turner B, Bihler H, Harrington J, Lapey A, Channick C, Keyes C, Freund A, Artandi S, Mense M, Rowe S, Engelhardt JF, Hsu YC, Rajagopal J. Dual SMAD signaling inhibition enables long-term expansion of diverse epithelial basal cells. Cell Stem Cell 2016; 19: 217-231. doi: https://doi.org/10. 1016/j.stem.2016.05.012. [PMID: PMC4975684.

28. Suzuki D, Pinto F, Senoo M. Inhibition of TGF-beta signaling promotes expansion of human epidermal keratinocytes in feeder cell co-culture. Wound repair and regeneration: official publication of the Wound Healing Society [and] the European Tissue Repair Society 2017; 25: 526-531. doi: https://doi.org/10.1111/wrr.12541. [PMID: PMC5568930.

29. Nakajima R, Takeda S. Efficient fabrication of epidermal cell sheets using gamma-secretase inhibitor. J Dermatol Sci 2014; 76: 246-254. doi: https://doi. org/10.1016/j.jdermsci.2014.09.006. [PMID: 25445926.

30. Chapman S, Liu X, Meyers C, Schlegel R, McBride AA. Human keratinocytes are efficiently immortalized by a rho kinase inhibitor. The Journal of clinical investigation 2010; 120: 2619-2626. doi: https://doi.org/10.1172/JCI42297. [PMID: PMC2898606.

31. Terunuma A, Limgala RP, Park CJ, Choudhary I, Vogel JC. Efficient procurement of epithelial stem cells from human tissue specimens using a rho-associated protein kinase inhibitor Y-27632. Tissue Eng Part A. 2010;16: 1363-8. https://doi.org/10.1089/ten.TEA.2009.0339 [PMID: PMC2862604.

32. Ji SZ, Xiao SC, Luo PF, Huang GF, Wang GY, Zhu SH, Wu MJ, Xia ZF. An epidermal stem cells niche microenvironment created by engineered human amniotic membrane. Biomaterials. 2011;32:7801-11. https://doi.org/ 10.1016/j.biomaterials.2011.06.076 [PMID: 21803416.

33. Hoess RH, Abremski K. Interaction of the bacteriophage P1 recombinase Cre with the recombining site loxP. Proc Natl Acad Sci U S A. 1984;81:1026-9. https://doi.org/10.1073/pnas.81.4.1026 [PMID: PMC344756.

34. Kretzschmar K, Watt FM. Lineage tracing. Cell. 2012;148:33-45. https://doi. org/10.1016/j.cell.2012.01.002 [PMID: 22265400.

35. Zinyk DL, Mercer EH, Harris E, Anderson DJ, Joyner AL. Fate mapping of the mouse midbrain-hindbrain constriction using a site-specific recombination system. Curr Biol. 1998;8:665-72. https://doi.org/10.1016/s09609822(98)70255-6 [PMID: 9635195.

36. Vasioukhin V, Degenstein L, Wise B, Fuchs E. The magical touch: genome targeting in epidermal stem cells induced by tamoxifen application to mouse skin. Proc Natl Acad Sci U S A. 1999;96:8551-6. https://doi.org/10. 1073/pnas.96.15.8551 [PMID: PMC17554.

37. Soriano P. Generalized lacZ expression with the ROSA26 Cre reporter strain. Nat Genet. 1999;21:70-1. https://doi.org/10.1038/5007 [PMID: 9916792.

38. Mao X, Fujiwara Y, Chapdelaine A, Yang H, Orkin SH. Activation of EGFP expression by Cre-mediated excision in a new ROSA26 reporter mouse strain. Blood 2001; 97: 324-326. doi: https://doi.org/10.1182/blood.v97.1.324. [PMID: 11133778. 
39. Madisen L, Zwingman TA, Sunkin SM, Oh SW, Zariwala HA, Gu H, Ng LL, Palmiter RD, Hawrylycz MJ, Jones AR, Lein ES, Zeng H. A robust and highthroughput Cre reporting and characterization system for the whole mouse brain. Nature neuroscience 2010; 13: 133-140. doi: https://doi.org/10.1038/ nn.2467. [PMID: PMC2840225.

40. Snippert HJ, van der Flier LG, Sato T, van Es JH, van den Born M, KroonVeenboer C, Barker N, Klein AM, van Rheenen J, Simons BD, Clevers H. Intestinal crypt homeostasis results from neutral competition between symmetrically dividing Lgr5 stem cells. Cell 2010; 143: 134-144. doi: https://doi.org/10.1016/j.cell.2010.09.016. [PMID: 20887898.

41. Kretzschmar K, Watt FM. Markers of epidermal stem cell subpopulations in adult mammalian skin. Cold Spring Harb Perspect Med 2014; 4: doi: https://doi.org/10.1101/cshperspect.a013631. [PMID: PMC4200210.

42. Jensen KB, Driskell RR, Watt FM. Assaying proliferation and differentiation capacity of stem cells using disaggregated adult mouse epidermis. Nat Protoc 2010; 5: 898-911. doi: https://doi.org/10.1038/nprot.2010.39. [PMID: 20431535

43. Claudinot S, Nicolas M, Oshima H, Rochat A, Barrandon Y. Long-term renewal of hair follicles from clonogenic multipotent stem cells. Proc Natl Acad Sci U S A 2005; 102: 14677-14,682. doi: https://doi.org/10.1073/pnas. 0507250102. [PMID: PMC1253596.

44. Morris RJ, Liu Y, Marles L, Yang Z, Trempus C, Li S, Lin JS, Sawicki JA, Cotsarelis G. Capturing and profiling adult hair follicle stem cells. Nat Biotechnol 2004; 22: 411-417. doi: https://doi.org/10.1038/nbt950. [PMID: 15024388.

45. Cotsarelis G, Sun TT, Lavker RM. Label-retaining cells reside in the bulge area of pilosebaceous unit: implications for follicular stem cells, hair cycle, and skin carcinogenesis. Cell 1990; 61: 1329-1337. doi: https://doi.org/10. 1016/0092-8674(90)90696-c. [PMID: 2364430

46. Braun KM, Niemann C, Jensen UB, Sundberg JP, Silva-Vargas V, Watt FM. Manipulation of stem cell proliferation and lineage commitment: visualization of label-retaining cells in wholemounts of mouse epidermis. Development 2003; 130: 5241-5255. doi: https://doi.org/10.1242/dev.00703. [PMID: 12954714.

47. Hinojosa-Godinez A, Jave-Suarez LF, Flores-Soto M, Galvez-Contreras AY, Luquin S, Oregon-Romero E, Gonzalez-Perez O, Gonzalez-Castaneda RE. Melatonin modifies SOX2(+) cell proliferation in dentate gyrus and modulates SIRT1 and MECP2 in long-term sleep deprivation. Neural Regen Res 2019; 14: 1787-1795. doi: https://doi.org/10.4103/1673-5374.257537. [PMID: PMC6585545.

48. Bickenbach JR, Chism E. Selection and extended growth of murine epidermal stem cells in culture. Exp Cell Res 1998; 244: 184-195. doi: https://doi.org/10.1006/excr.1998.4163. [PMID: 9770361.

49. Snippert HJ, Clevers H. Tracking adult stem cells. EMBO Rep 2011; 12: 113-122. doi: https://doi.org/10.1038/embor.2010.216. [PMID: PMC3049439

50. Steinhauser ML, Bailey AP, Senyo SE, Guillermier C, Perlstein TS, Gould AP, Lee RT, Lechene CP. Multi-isotope imaging mass spectrometry quantifies stem cell division and metabolism. Nature 2012; 481: 516-519 doi: https://doi.org/10.1038/nature10734. [PMID: PMC3267887.

51. Tumbar T, Guasch G, Greco V, Blanpain C, Lowry WE, Rendl M, Fuchs E. Defining the epithelial stem cell niche in skin. Science 2004; 303: 359-363. doi: https://doi.org/10.1126/science.1092436. [PMID: PMC2405920.

52. Uffe B. Jensen, Sally Lowell, Watt. FM. The spatial relationship between stem cells and their progeny in the basal layer of human epidermis: a new view based on whole-mount labelling and lineage analysis. Development 1999; 126: 2409-2418 [PMID: 10226000,

53. Kolodka TM, Garlick JA, Taichman LB. Evidence for keratinocyte stem cells in vitro: long term engraftment and persistence of transgene expression from retrovirus-transduced keratinocytes. Proc Natl Acad Sci U S A 1998; 95: 4356-4361.doi: https://doi.org/10.1073/pnas.95.8.4356. [PMID: PMC22493.

54. Kaur P, Li A, Redvers R, Bertoncello I. Keratinocyte stem cell assays: an evolving science. J Investig Dermatol Symp Proc. 2004;9:238-47. https://doi. org/10.1111/j.1087-0024.2004.09306.x.

55. Gallico GG, 3rd, O"Connor NE, Compton CC, Kehinde O, Green H. Permanent coverage of large burn wounds with autologous cultured human epithelium. N Engl J Med 1984; 311: 448-451. doi: https://doi.org/10. 1056/NEJM198408163110706. [PMID: 6379456

56. Green H. The birth of therapy with cultured cells. Bioessays 2008; 30: 897903. doi: https://doi.org/10.1002/bies.20797. [PMID: 18693268.
57. Barrandon Y, Green $\mathrm{H}$. Three clonal types of keratinocyte with different capacities for multiplication. Proc Natl Acad Sci U S A 1987; 84: 2302-2306. doi: https://doi.org/10.1073/pnas.84.8.2302. [PMID: PMC304638.

58. Jones PH, Harper S, Watt FM. Stem cell patterning and fate in human epidermis. Cell 1995; 80: 83-93. doi: https://doi.org/10.1016/00928674(95)90453-0. [PMID: 7813021.

59. Zhu AJ, Haase I, Watt FM. Signaling via beta1 integrins and mitogenactivated protein kinase determines human epidermal stem cell fate in vitro. Proc Natl Acad Sci U S A 1999; 96: 6728-6733. doi: https://doi.org/ 10.1073/pnas.96.12.6728. [PMID: PMC21983.

60. Jahoda CA, Christiano AM. Niche crosstalk: intercellular signals at the hair follicle. Cell 2011; 146: 678-681. doi: https://doi.org/10.1016/j.cell.2011.08.020. [PMID: 21884930.

61. Driskell RR, Watt FM. Understanding fibroblast heterogeneity in the skin. Trends Cell Biol 2015; 25: 92-99. doi: https://doi.org/10.1016/j.tcb.2014.10. 001. [PMID: 25455110

62. Rognoni E, Watt FM. Skin cell heterogeneity in development, wound healing, and cancer. Trends Cell Biol 2018; 28: 709-722. doi: https:/doi.org/ 10.1016/j.tcb.2018.05.002. [PMID: PMC6098245.

63. Huh SH, Narhi K, Lindfors PH, Haara O, Yang L, Ornitz DM, Mikkola ML. Fgf2O governs formation of primary and secondary dermal condensations in developing hair follicles. Genes Dev 2013; 27: 450-458. doi: https://doi.org/ 10.1101/gad.198945.112. [PMID: PMC3589561.

64. Telerman SB, Rognoni E, Sequeira I, Pisco AO, Lichtenberger BM, Culley OJ, Viswanathan P, Driskell RR, Watt FM. Dermal Blimp1 acts downstream of epidermal TGFbeta and Wnt/beta-catenin to regulate hair follicle formation and growth. The Journal of investigative dermatology 2017; 137: 2270-2281. doi: https://doi.org/10.1016/j.jid.2017.06.015. [PMID: PMC5646946.

65. Zhang Y, Andl T, Yang SH, Teta M, Liu F, Seykora JT, Tobias JW, Piccolo S, Schmidt-Ullrich R, Nagy A, Taketo MM, Dlugosz AA, Millar SE. Activation of beta-catenin signaling programs embryonic epidermis to hair follicle fate. Development 2008; 135: 2161-2172. doi: https://doi.org/10.1242/dev.017459. [PMID: PMC2516408

66. Collins CA, Jensen KB, MacRae EJ, Mansfield W, Watt FM. Polyclonal origin and hair induction ability of dermal papillae in neonatal and adult mouse back skin. Dev Biol 2012; 366: 290-297. [PMID: PMC3384004 doi: https://doi. org/10.1016/j.ydbio.2012.03.016.

67. Yang H, Adam RC, Ge Y, Hua ZL, Fuchs E. Epithelial-mesenchymal microniches govern stem cell lineage choices. Cell 2017; 169: $483-496$ e413. doi: https://doi.org/10.1016/j.cell.2017.03.038. [PMID: PMC5510744.

68. Lu CP, Polak L, Keyes BE, Fuchs E. Spatiotemporal antagonism in mesenchymal-epithelial signaling in sweat versus hair fate decision. Science 2016; 354. doi: https://doi.org/10.1126/science.aah6102. [PMID: PMC5333576.

69. Poblet $E$, Jimenez $F$, Ortega F. The contribution of the arrector pili muscle and sebaceous glands to the follicular unit structure. J Am Acad Dermatol 2004; 51: 217-222. doi: https://doi.org/10.1016/j.jaad.2004.01.054. [PMID: 15280840.

70. Fujiwara H, Ferreira M, Donati G, Marciano DK, Linton JM, Sato Y, Hartner A, Sekiguchi K, Reichardt LF, Watt FM. The basement membrane of hair follicle stem cells is a muscle cell niche. Cell 2011; 144: 577-589. doi: https://doi. org/10.1016/j.cell.2011.01.014. [PMID: PMC3056115.

71. Akiyama M, Dale BA, Sun TT, Holbrook KA. Characterization of hair follicle bulge in human fetal skin: the human fetal bulge is a pool of undifferentiated keratinocytes. The Journal of investigative dermatology 1995; 105: 844-850.doi: https://doi.org/10.1111/1523-1747.ep12326649. [PMID: 7490481.

72. Brandenberger R, Schmidt A, Linton J, Wang D, Backus C, Denda S, Muller U, Reichardt LF. Identification and characterization of a novel extracellular matrix protein nephronectin that is associated with integrin alpha8beta1 in the embryonic kidney. J Cell Biol 2001; 154: 447-458. doi: https://doi.org/10. 1083/jcb.200103069. [PMID: PMC2150762.

73. Driskell RR, Giangreco A, Jensen KB, Mulder KW, Watt FM. Sox2-positive dermal papilla cells specify hair follicle type in mammalian epidermis. Development 2009; 136: 2815-2823. doi: https://doi.org/10.1242/dev.038620. [PMID: PMC2730408.

74. Sato Y, Uemura T, Morimitsu K, Sato-Nishiuchi R, Manabe R, Takagi J, Yamada M, Sekiguchi K. Molecular basis of the recognition of nephronectin by integrin alpha8beta1. J Biol Chem. 2009;284:14524-14,536. https://doi. org/10.1074/jbc.M900200200 [PMID: PMC2682901.

75. Donati G, Proserpio V, Lichtenberger BM, Natsuga $K$, Sinclair R, Fujiwara $H$, Watt FM. Epidermal Wnt/beta-catenin signaling regulates adipocyte 
differentiation via secretion of adipogenic factors. Proc Natl Acad Sci U S A. 2014;111:E1501-9. https://doi.org/10.1073/pnas.1312880111 [PMID: PMC3992657.

76. Festa E, Fretz J, Berry R, Schmidt B, Rodeheffer M, Horowitz M, Horsley V. Adipocyte lineage cells contribute to the skin stem cell niche to drive hair cycling. Cell. 2011;146:761-71. https://doi.org/10.1016/j.cell.2011.07.019 [PMID: PMC3298746.

77. Plikus MV, Mayer JA, de la Cruz D, Baker RE, Maini PK, Maxson R, Chuong CM. Cyclic dermal BMP signalling regulates stem cell activation during hai regeneration. Nature. 2008;451:340-4. https://doi.org/10.1038/nature06457 [PMID: PMC2696201.

78. Fuchs $E$, Chen T. A matter of life and death: self-renewal in stem cells. EMBO Rep. 2013;14:39-48. https://doi.org/10.1038/embor.2012.197 [PMID: PMC3537149.

79. Zhang B, Tsai PC, Gonzalez-Celeiro M, Chung O, Boumard B, Perdigoto CN, Ezhkova E, Hsu YC. Hair follicles' transit-amplifying cells govern concurrent dermal adipocyte production through sonic hedgehog. Genes Dev. 2016;30: 2325-38. https://doi.org/10.1101/gad.285429.116 [PMID: PMC5110998.

80. Fujiwara H, Tsutsui K, Morita R. Multi-tasking epidermal stem cells: beyond epidermal maintenance. Dev Growth Differ. 2018;60:531-41. https://doi.org/ 10.1111/dgd.12577 [PMID: 30449051.

81. Li LS, Ginty DD. The structure and organization of lanceolate mechanosensory complexes at mouse hair follicles. Elife 2014; 3. doi: ARTN e01901 10.7554/eLife.01901. [PMID: PMC3930909.

82. Botchkarev VA, Eichmuller S, Johansson O, Paus R. Hair cycle-dependent plasticity of skin and hair follicle innervation in normal murine skin. J Comp Neurol 1997; 386: 379-395. doi: 10.1002/(sici)1096-9861(19970929)386:3 < 379::aid-cne4>3.0.co;2-z. [PMID: 9303424

83. Brownell I, Guevara E, Bai CB, Loomis CA, Joyner AL. Nerve-derived sonic hedgehog defines a niche for hair follicle stem cells capable of becoming epidermal stem cells. Cell Stem Cell. 2011;8:552-65. https://doi.org/10.1016/j. stem.2011.02.021 [PMID: PMC3089905.

84. Rutlin M, Ho CY, Abraira VE, Cassidy C, Bai L, Woodbury CJ, Ginty DD. The cellular and molecular basis of direction selectivity of Adelta-LTMRs. Cell. 2015;160:1027. https://doi.org/10.1016/j.cell.2015.02.013 [PMID: 29698636.

85. Zimmerman A, Bai L, Ginty DD. The gentle touch receptors of mammalian skin. Science. 2014;346:950-4. https://doi.org/10.1126/science.1254229 [PMID: PMC4450345.

86. Cheng CC, Tsutsui K, Taguchi T, Sanzen N, Nakagawa A, Kakiguchi K, Yonemura S, Tanegashima C, Keeley SD, Kiyonari H, Furuta Y, Tomono $Y$ Watt FM, Fujiwara H. Hair follicle epidermal stem cells define a niche for tactile sensation. Elife. 2018;7. https://doi.org/10.7554/eLife.38883 [PMID: PMC6226291.

87. Stoppel WL, Ghezzi CE, McNamara SL, Black LD 3rd, Kaplan DL. Clinical applications of naturally derived biopolymer-based scaffolds for regenerative medicine. Ann Biomed Eng. 2015;43:657-80. https://doi.org/10. 1007/s10439-014-1206-2 [PMID: 25537688

88. Kohane DS, Langer R. Polymeric biomaterials in tissue engineering. Pediatr Res. 2008:63:487-91. https://doi.org/10.1203/01.pdr.0000305937.26105.e7 [PMID: 18427292.

89. Yen CM, Shen CC, Yang YC, Liu BS, Lee HT, Sheu ML, Tsai MH, Cheng WY. Novel electrospun poly(epsilon-caprolactone)/type i collagen nanofiber conduits for repair of peripheral nerve injury. Neural Regen Res. 2019:14: 1617-25. https://doi.org/10.4103/1673-5374.255997 [PMID: PMC6557087.

90. Lough DM, Wetter N, Madsen C, Reichensperger J, Cosenza N, Cox L, Harrison C, Neumeister MW. Transplantation of an lgr6+ epithelial stem cell-enriched scaffold for repair of full-thickness soft-tissue defects: the in vitro development of polarized hair-bearing skin. Plast Reconstr Surg. 2016;137:495-507. https://doi.org/10.1097/01.prs.0000475761.09451.00 [PMID: 26818284.

91. Almine JF, Bax DV, Mithieux SM, Nivison-Smith L, Rnjak J, Waterhouse A, Wise SG, Weiss AS. Elastin-based materials. Chem Soc Rev. 2010; 39: 33713379. doi: https://doi.org/10.1039/b919452p. [PMID: 20449520.

92. Wise SG, Mithieux SM, Weiss AS. Engineered tropoelastin and elastin-based biomaterials. Adv Protein Chem Struct Biol 2009; 78: 1-24. doi: https://doi. org/10.1016/S1876-1623(08)78001-5. [PMID: 20663482.

93. Xie SY, Peng LH, Shan YH, Niu J, Xiong J, Gao JQ. Adult stem cells seeded on electrospinning silk fibroin nanofiberous scaffold enhance wound repair and regeneration. J Nanosci Nanotechnol 2016; 16: 5498-5505. doi: https://doi.org/10.1166/jnn.2016.11730. [PMID: 27427589.

94. Chlapanidas T, Tosca MC, Farago S, Perteghella S, Galuzzi M, Lucconi G, Antonioli B, Ciancio F, Rapisarda V, Vigo D, Marazzi M, Faustini M, Torre ML.
Formulation and characterization of silk fibroin films as a scaffold for adipose-derived stem cells in skin tissue engineering. Int J Immunopatho Pharmacol 2013; 26: 43-49. doi: https://doi.org/10.1177/ 03946320130260S106. [PMID: 24046948.

95. Mauck RL, Yuan X, Tuan RS. Chondrogenic differentiation and functional maturation of bovine mesenchymal stem cells in long-term agarose culture. Osteoarthritis Cartilage 2006; 14: 179-189. doi: https://doi.org/10.1016/j.joca. 2005.09.002. [PMID: 16257243.

96. Hannouche D, Terai H, Fuchs JR, Terada S, Zand S, Nasseri BA, Petite H, Sedel L, Vacanti JP. Engineering of implantable cartilaginous structures from bone marrow-derived mesenchymal stem cells. Tissue Eng 2007; 13: 87-99. doi: https://doi.org/10.1089/ten.2006.0067. [PMID: 17518583.

97. Ashton RS, Banerjee A, Punyani S, Schaffer DV, Kane RS. Scaffolds based on degradable alginate hydrogels and poly(lactide-co-glycolide) microspheres for stem cell culture. Biomaterials 2007; 28: 5518-5525. doi: https://doi.org/ 10.1016/j.biomaterials.2007.08.038, [PMID: 17881048.

98. Charruyer A, Fong S, Yue L, Arron ST, Ghadially R. Phycosaccharide Al, a mixture of alginate polysaccharides, increases stem cell proliferation in aged keratinocytes. Experimental dermatology 2016; 25: 738-740. doi: https://doi. org/10.1111/exd.13051. [PMID: 27095184.

99. Zhao J, Liu LQ, Wang YJ, Yang W, Geng WX, Wei J, Li LW, Chen FL. Treatment of alopecia by transplantation of hair follicle stem cells and dermal papilla cells encapsulated in alginate gels. Med Hypotheses. 2008;70: 1014-6. https://doi.org/10.1016/j.mehy.2007.09.001 [PMID: 17936520.

100. Li Z, Huang S, Liu Y, Yao B, Hu T, Shi H, Xie J, Fu X. Tuning alginate-gelatin bioink properties by varying solvent and their impact on stem cell behavior. Sci Rep. 2018;8:8020. https://doi.org/10.1038/s41598-018-26,407-3 [PMID: PMC5964146.

101. Dawson E, Mapili G, Erickson K, Taqvi S, Roy K. Biomaterials for stem cell differentiation. Adv Drug Deliv Rev. 2008;60:215-28. https://doi.org/10.1016/ j.addr.2007.08.037 [PMID: 17997187.

102. Ghasemi-Mobarakeh L, Prabhakaran MP, Tian L, Shamirzaei-Jeshvaghani E, Dehghani L, Ramakrishna S. Structural properties of scaffolds: crucial parameters towards stem cells differentiation. World J Stem Cells. 2015;7: 728-44. https://doi.org/10.4252/wjsc.v7.i4.728 [PMID: PMC4444613.

103. Kim KL, Han DK, Park K, Song SH, Kim JY, Kim JM, Ki HY, Yie SW, Roh CR, Jeon ES, Kim DK, Suh W. Enhanced dermal wound neovascularization by targeted delivery of endothelial progenitor cells using an RGD-g-PLLA scaffold. Biomaterials. 2009;30:3742-8. https://doi.org/10.1016/j.biomaterials. 2009.03.053 [PMID: 19394079.

104. Yang F, Cho SW, Son SM, Bogatyrev SR, Singh D, Green JJ, Mei Y, Park S, Bhang SH, Kim BS, Langer R, Anderson DG. Genetic engineering of human stem cells for enhanced angiogenesis using biodegradable polymeric nanoparticles. Proc Natl Acad Sci U S A. 2010;107:3317-22. https://doi.org/ 10.1073/pnas.0905432106 [PMID: PMC2840438.

105. Michael S, Sorg H, Peck CT, Koch L, Deiwick A, Chichkov B, Vogt PM, Reimers K. Tissue engineered skin substitutes created by laser-assisted bioprinting form skin-like structures in the dorsal skin fold chamber in mice. PloS one. 2013;8:e57741. https://doi.org/10.1371/journal.pone.0057741 [PMID: PMC3587634

106. Auxenfans C, Fradette J, Lequeux C, Germain L, Kinikoglu B, Bechetoille N, Braye F, Auger FA, Damour O. Evolution of three dimensional skin equivalent models reconstructed in vitro by tissue engineering. Eur J Dermatol. 2009;19:107-13. https://doi.org/10.1684/ejd.2008.0573 [PMID: 19106039.

107. Jakab K, Norotte C, Marga F, Murphy K, Vunjak-Novakovic G, Forgacs G. Tissue engineering by self-assembly and bio-printing of living cells. Biofabrication. 2010;2:022001. https://doi.org/10.1088/1758-5082/2/2/022001 [PMID: PMC3635954.

108. Ramanathan G, Singaravelu S, Muthukumar T, Thyagarajan S, Perumal PT, Sivagnanam UT. Design and characterization of 3D hybrid collagen matrixes as a dermal substitute in skin tissue engineering. Mater Sci Eng C Mater Biol Appl. 2017;72:359-70. https://doi.org/10.1016/j.msec.2016.11.095 [PMID: 28024598 .

109. Wang X, Li X, Li Y, Zhou Y, Fan C, Li W, Ma S, Fan Y, Huang Y, Li N, Liu Y. Synthesis, characterization and biocompatibility of poly(2-ethyl-2-oxazoline)poly(d,I-lactide)-poly(2-ethyl-2-oxazoline) hydrogels. Acta Biomater 2011; 7: 4149-4159. doi: https://doi.org/10.1016/j.actbio.2011.07.011. [PMID: 21810488.

110. Lee V, Singh G, Trasatti JP, Bjornsson C, Xu X, Tran TN, Yoo SS, Dai G, Karande P. Design and fabrication of human skin by three-dimensional 
bioprinting. Tissue Eng Part C Methods. 2014;20:473-84. https://doi.org/10. 1089/ten.TEC.2013.0335 [PMID: PMC4024844.

111. Du J, Jia X. Engineering nerve guidance conduits with three-dimenisonal bioprinting technology for long gap peripheral nerve regeneration. Neural Regen Res. 2019;14:2073-4. https://doi.org/10.4103/1673-5374.262580 [PMID: PMC6788239.

112. Auxenfans C, Lequeux C, Perrusel E, Mojallal A, Kinikoglu B, Damour O. Adipose-derived stem cells (ASCs) as a source of endothelial cells in the reconstruction of endothelialized skin equivalents. J Tissue Eng Regen Med. 2012;6:512-8. https://doi.org/10.1002/term.454 [PMID: 21755603.

113. Ong CS, Yesantharao P, Huang CY, Mattson G, Boktor J, Fukunishi T, Zhang H, Hibino N. 3D bioprinting using stem cells. Pediatr Res. 2018;83:223-31. https://doi.org/10.1038/pr.2017.252 [PMID: 28985202.

114. Huang S, Yao B, Xie J, Fu X. 3D bioprinted extracellular matrix mimics facilitate directed differentiation of epithelial progenitors for sweat gland regeneration. Acta Biomater. 2016;32:170-7. https://doi.org/10.1016/j.actbio. 2015.12.039 [PMID: 26747979.

115. Rasch A. Fifth congress of industrial cell technology 2014. Regen Med. 2015; 10:105-7. https://doi.org/10.2217/rme.14.90 [PMID: 25835476.

116. Supp DM, Boyce ST. Engineered skin substitutes: practices and potentials. Clin Dermatol. 2005;23:403-12. https://doi.org/10.1016/j.clindermatol.2004. 07.023 [PMID: 16023936.

117. Hou X, Liu S, Wang M, Wiraja C, Huang W, Chan P, Tan T, Xu C. Layer-bylayer 3D constructs of fibroblasts in hydrogel for examining transdermal penetration capability of nanoparticles. SLAS Technol. 2017;22:447-53. https://doi.org/10.1177/2211068216655753 [PMID: 27325107.

118. Golchin A, Farahany TZ. Biological products: cellular therapy and FDA approved products. Stem Cell Rev. Rep. 2019;15:166-75. https://doi.org/10. 1007/s12015-018-9866-1.

119. Schmidt C. Gintuit cell therapy approval signals shift at US regulator. Nat Biotechnol. 2012;30:479. https://doi.org/10.1038/nbt0612-479.

120. Gentile P, Piccinno M, Calabrese C. Characteristics and potentiality of human adipose-derived stem cells (hASCs) obtained from enzymatic digestion of fat graft. Cells. 2019;8. https://doi.org/10.3390/cells8030282.

121. Gentile P, Kothari A, Casella D, Calabrese C. Fat graft enhanced with adipose-derived stem cells in aesthetic breast augmentation: clinical, histological, and instrumental evaluation. Esthetic Aesthetic Surgery Journal. 2019. https://doi.org/10.1093/asj/sjz292.

122. Gentile P, Casella D, Palma E, Calabrese C. Engineered fat graft enhanced with adipose-derived stromal vascular fraction cells for regenerative medicine: clinical, histological and instrumental evaluation in breast reconstruction. J Clin Med. 2019;8. https://doi.org/10.3390/jcm8040504

123. Gentile P, Garcovich S. Concise review: adipose-derived stem cells (ASCs) and adipocyte-secreted exosomal microRNA (A-SE-miR) modulate cancer growth and promote wound repair. J Clin Med. 2019;8. https://doi.org/10. 3390/jcm8060855.

124. Scioli MG, Bielli A, Gentile P, Cervelli V, Orlandi A. Combined treatment with platelet-rich plasma and insulin favours chondrogenic and osteogenic differentiation of human adipose-derived stem cells in three-dimensional collagen scaffolds. J Tissue Eng Regen Med. 2017;11:2398-410. https://doi. org/10.1002/term.2139.

125. Gentile P, Scioli MG, Bielli A, Orlandi A, Cervelli V. Concise review: the use of adipose-derived stromal vascular fraction cells and platelet rich plasma in regenerative plastic surgery. Stem Cells. 2017;35:117-34. https://doi.org/10. 1002/stem.2498.

126. Gentile P. Autologous cellular method using micrografts of human adipose tissue derived follicle stem cells in androgenic alopecia. Int J Mol Sci. 2019; 20. https://doi.org/10.3390/ijms20143446 [PMID: PMC6678214.

127. Gentile P, Scioli MG, Bielli A, Orlandi A, Cervelli V. Stem cells from human hair follicles: first mechanical isolation for immediate autologous clinical use in androgenetic alopecia and hair loss. Stem Cell Investig. 2017;4:58. https://doi.org/10.21037/sci.2017.06.04 [PMID: PMC5504091.

128. Gentile P, Scioli MG, Cervelli V, Orlandi A, Garcovich S. Autologous micrografts from scalp tissue: trichoscopic and long-term clinical evaluation in male and female androgenetic alopecia. Biomed Res Int. 2020;2020: 7397162. https://doi.org/10.1155/2020/7397162 [PMID: PMC7007958.

129. Gentile P, Scioli MG, Bielli A, De Angelis B, De Sio C, De Fazio D, Ceccarelli G, Trivisonno A, Orlandi A, Cervelli V, Garcovich S. Platelet-rich plasma and micrografts enriched with autologous human follicle mesenchymal stem cells improve hair re-growth in androgenetic alopecia. Biomolecular pathway analysis and clinical evaluation.
Biomedicines 2019; 7. doi: https://doi.org/10.3390/biomedicines7020027. [PMID: PMC6631937.

130. Gentile P, Garcovich S. Advances in regenerative stem cell therapy in androgenic alopecia and hair loss: Wnt pathway, growth-factor, and mesenchymal stem cell signaling impact analysis on cell growth and hair follicle development. Cells. 2019;8. https://doi.org/10.3390/cells8050466 [PMID: PMC6562814.

\section{Publisher's Note}

Springer Nature remains neutral with regard to jurisdictional claims in published maps and institutional affiliations. 